\title{
Pedagogia do Esporte: O Basquete de Rua praticado na Região Metropolitana de Campinas
}

\author{
Douglas V. C. Brasil*, Roberto Rodrigues Paes
}

\section{Resumo}

Através de pesquisa bibliográfica/documental ${ }^{8}$ buscou-se compreender/caracterizar o Basquete de Rua e o Streetball. Após, foi realizada pesquisa de observação não participante ${ }^{8}$ em cidades da Região Metropolitana de Campinas (RMC). Por fim, comparamos os dados da pesquisa de campo com a documental/bibliográfica buscando assim compreender o Basquete de Rua da RMC.

\section{Palavras-chave: Pedagogia do Esporte,Basquete de Rua, Basquetebol}

\section{Introdução}

A Pedagogia do Esporte, tem como objeto de estudo e intervenção do processo de ensino, vivência, aprendizagem e treinamento do esporte, obtendo e acumulando conhecimento significativo a respeito da organização, sistematização, aplicação e avaliação das práticas esportivas nas suas diversas manifestações e sentidos ${ }^{5}$. Neste contexto, podemos identificar três referenciais: técnico-tático, que trabalha com os fundamentos técnicos, princípios táticos das modalidades esportivas, buscando responder a três questões: o que, como e onde ensinar?; socioeducativo, responsável por trabalhar valores e modos de comportamento; e históricocultural, o qual aborda a evolução histórica das modalidades, evolução das regras, papel da mídia, entre outros ${ }^{4}$. Através do referencial histórico-cultural, buscouse compreender/caracterizar o Streetball e o Basquete de Rua. Para tal foi necessário compreender o surgimento e desenvolvimento do basquetebol, modalidade idealizada/criada por James Naismith², já que a partir deste teriam surgido o Streetball nas ruas dos Estados Unidos da América (EUA) ${ }^{1 ; 6}$.

\section{Resultados e Discussão}

Em pesquisa nas bases de dados - SBU e SIBiUSP, limitada a artigos (periódicos), dissertação/tese e livro impresso/eletrônico, indicou um baixo número de resultados com as palavras chaves "basquete $3 \times 3$ ", "streetball" e "basquete de rua" (60 ocorrências) em comparação a busca da palavra-chave "basquetebol" (899 ocorrências), indicando a necessidade de novas pesquisas acerca do tema.

O Streetball, teria surgido em Washington ou Nova York nos EUA, na década de 1960. Apesar de similar ao basquetebol, na pratica o Streetball possui regras que variam de quadra para quadra, por vezes deixando o objetivo de fazer a cesta em segundo plano, valorizando jogadas que entretenham o público e que deixam os adversários sem jeito, podendo utilizar qualquer parte do corpo para isso ${ }^{1,6}$.

Já no Brasil, a primeira menção ao termo Streetball e Basquete de Rua (adaptação do termo norte americano) data de $1993^{3}$, referindo-se a uma competição disputada no formato três contra três. Nos anos 2000 organizações/instituições se apropriaram do termo Basquete de Rua e criaram competições e equipes cada uma com seu propósito?.
Na RMC, através da pesquisa de campo (em 5 quadras públicas de 3 cidades: Cosmópolis; Sumaré; Campinas), notou-se que a pratica é muito próxima ao Streetball norte americano, com algumas adaptações em relação as regras do basquetebol, variando de quadra para quadra, porém com um número baixo de ocorrência de dribles característicos do Basquete de Rua e outros elementos ${ }^{0}$, o principal nestas quadras é fazer a cesta, pontuar e vencer.

\section{Conclusão}

Não encontramos estudos que apontem como era a pratica do Basquete de Rua na RMC. Ao que tudo indica, assim como acontece no $\mathrm{RJ}^{7}$, com o fim das competições e consequente diminuição das equipes, a prática do Basquete de Rua tem se tornado cada vez mais próxima a do basquetebol, onde dribles que embaraçam o adversário e/ou entretém o público, estão deixando de ter sua importância, passando a importar a vitória.

\section{Agradecimentos}

Ao grupo GEPESP da FEF-Unicamp. Ao CNPQ e PIBIC pela oportunidade de desenvolvimento de minha pesquisa.

${ }^{0}$ ATHAYDE, C. Manual Basquete de Rua. Rio de Janeiro: CUFA, [2011?]. 'DOIN' IT IN THE PARK: Pick-Up Basketball, New York City. New York. Direção de Bobbito Garcia e Kevin Couliau, 2012. Documentário. Disponível em: <http://buy.doinitinthepark.com/>. Acessado em: 06 de abril de 2015. ${ }^{2}$ FREITAS, A; VIEIRA, S. O que é basquete: história, regras, curiosidades. Rio de Janeiro: Casa da Palavra, 2006.

${ }^{3}$ FUNDAÇÃO BIBLIOTECA NACIONAL. Hemeroteca Digital. 2016. Disponível em: <http://bndigital.bn.br/hemeroteca-digital/>. Acesso em: $17 \mathrm{de}$ fev. de 2015.

${ }^{4}$ GALLATI, L. R.; MACHADO G. V.; PAES R. R. Pedagogia do esporte e o referencial histórico-cultural: Interlocução entre teoria e prática. Revista Pensar a Prática, Goiânia, v. 17, n. 2, p. 414-430, 2014

${ }^{5}$ GAlATtI, L. R.; REVERDITO, R. S.; SCAGLiA, A. J.; PAES, R. R.; SEOANE, M. A. Pedagogia do esporte: tensão na ciência e o ensino dos jogos esportivos coletivos. Revista da Educação Física.UEM, Maringá, v. 25, n. 1, p. 153-162, mar. 2014.

${ }^{6}$ HORN, L. The history behind Red Bull King of the Rock. 30 de ago. de 2014. Disponível em: < http:/www.redbull.com/en/stories/1331675240605/thehistory-of-streetball-and-red-bull-king-of-the-rock $>$. Acesso em: 26 de nov. de 2015.

${ }^{7}$ JESUS, A. C. A.; VOTRE, S. Basquete de rua na cidade do Rio de Janeiro. Revista Pensar a Pratica, Goiânia, v15 n. 4, p. 933-947, 2012.

${ }^{8}$ MARCONI, M. A.; LAKATOS, E. M. Fundamentos de metodologia científica. 5. ed. São Paulo: Atlas, 2003. 